\title{
Rancang Bangun Media Pembelajaran Atlas ASEAN Berbasis Desktop
}

\author{
Herryansyah $^{1}$
}

\begin{abstract}
The rapid development of technology provides challenges that must be utilized in supporting science, including Social Sciences. On this occasion, we focus on the organization of Southeast Asian countries, namely ASEAN. So we need an Atlas ASEAN application which is expected to help in learning the ASEAN member countries more easily and interactively. This application is made using Visual Basic which is designed as attractive as possible to be used by various groups. Visual Basic was chosen to build this application, because of its ease and reliability to learn and its execution program that can run on any version of Windows.
\end{abstract}

Intisari- Perkembangan teknologi yang semakin pesat memberikan tantangan yang harus bisa dimanfaatkan dalam menunjang ilmu pengetahuan, termasuk Ilmu Pengetahuan Sosial. Pada kesempatan kali ini kita fokus pada organisasi negara-negara Asia Tenggara yaitu ASEAN. Maka diperlukan suatu aplikasi Atlas ASEAN yang diharapkan bisa membantu dalam mempelajari negara-negara anggota ASEAN tersebut dengan lebih mudah dan interaktif. Aplikasi ini dibuat dengan menggunakan Visual Basic yang dirancang semenarik mungkin untuk bisa digunakan oleh berbagai kalangan. Dipilihnya Visual Basic untuk membangun aplikasi ini, karena kemudahan dan kehandalannya untuk dipelajari dan program eksekusinya yang bisa dijalankan pada versi Windows manapun.

Kata Kunci-Atlas, ASEAN, Visual Basic, Media Interaktif.

\section{PENDAHULUAN}

Perkembangan teknologi dan informasi dewasa ini semakin pesat dan tak terkendali dan telah membawa umat manusia ke era informasi yang mengalir tanpa batas. Hal ini dapat kita rasakan dengan merambahnya aneka ragam kemudahan dalam memperoleh informasi disegala bidang kehidupan. Salah satu teknologi dan informasi yang berkembang sangat cepat adalah teknologi komputer. Yang sudah barang tentu pesatnya teknologi ini ditujukan untuk memberikan kontribusi dan dampak yang positif.

Dalam bidang pendidikan, penerapan teknologi komputer sudah banyak digunakan di berbagai lapisan, yang mana penggunaannya banyak membantu para pelajar dan para pengajar dalam proses belajar dan mengajar.

Adapun dipilihnya perancangan program aplikasi Atlas Asean ini, adalah untuk mencoba membuat suatu aplikasi siap pakai yang diharapkan dapat membantu para penggunanya dalam memahami tentang Ilmu Pengetahuan Sosial (IPS) khususnya tentang organisasi ASEAN.

${ }^{1}$ Program Studi Sistem Informasi Universitas Bina Sarana Informatika, Jl. Cut Mutia No.88, RT.001/RW.002, Sepanjang Jaya, Kec. Rawalumbu, Kota Bekasi, Jawa Barat 17113 tlp: (021)8000063; e-mail: herryansyah.hrr@bsi.ac.id
Dalam aplikasi Atlas Asean terdapat beberapa fungsi-fungsi penggunaan program yang cukup mudah dipahami dan mudah digunakan. Pengguna aplikasi Atlas Asean dapat meng-akses gambar peta, keterangan peta, keterangan ASEAN dan negara-negara anggotanya dengan cara yang sangat mudah yaitu dengan hanya meng-klik tombol-tombol akses yang terdapat pada aplikasi ini, dibandingkan dengan membukabuka halaman buku atlas dan buku-buku pengetahuan tentang ASEAN, yang mana umumnya kedua buku ini dikemas terpisah antara buku atlas dengan buku tentang ASEAN.

\section{TINJAUAN PUSTAKA}

\section{A. Media Pembelajaran}

Dalam perkembangan awal (dan hingga kini masih dianut), istilah media pembelajaran hanyalah berkisar guru, kapur tulis, dan buku paket. Sekarang ini media pembelajaran lebih cenderung dipandang sebagai alat untuk menyampaikan pembelajaran[1]. Definisi ini menekankan bahwa setiap peralatan fisik yang digunakan untuk menyajikan pembelajaran apakah buku paket, peralatan visual, audio, komputer, atau peralatan lainnya diklasifikasikan sebagai media pembelajaran[1].

Media pembelajaran mencakup semua peralatan fisik dan materi yang digunakan oleh instruktur, dosen, guru, tutor, atau pendidik lainnya dalam melaksanakan pembelajaran dan menfasilitasi tercapainya tujuan pembelajaran. Media pembelajaran yang dimaksud mencakup media tradisional yang terdiri atas kapur tulis, handout, diagram, slide, overhead, objek nyata, dan rekaman video, atau film dan media mutakhir seperti komputer, DVD, CD-ROM, Internet, dan konferensi video interaktif[1].

\section{B. Atlas}

Atlas merupakan sebagai suatu kumpulan peta yang disusun sedemikian rupa untuk maksud dan tujuan tertentu. Merupakan kumpulan peta-peta yang dirancang untuk disimpan dalam bentuk jilid ataupun dalam keadaan lepaslepas tetapi dikumpul menjadi satu[2].

Atlas yang baik harus memiliki unsur-unsur yang mudah dipahami oleh penggunanya. Untuk mengidentifikasi informasi geografis pada atlas, maka harus dikenali unsurunsurnya, sebagai berikut:

1. Judul, misalnya, Atlas Dunia

2. Kata Pengantar, yang berisikan isi dan tujuan atlas

3. Daftar Isi, memuat susunan peta-peta yang disajikan

4. Legenda, berisi keterangan mengenai simbol dan macammacam singkatan pada peta.

5. Isi, berisi bermacam-macam peta yang disajikan sesuai dengan judul atlas 
6. Daftar Indeks, daftar nama geografi yang terdapat dalam atlas[2].

\section{ASEAN}

ASEAN (Association of Southeast Asian Nations atau perhimpunan Bangsa-Bangsa Asia Tenggara) adalah organisasi kawasan yang mewadahi kerja sama 10 (sepuluh) negara di Asia Tenggara. ASEAN dibentuk tanggal 8 Agustus 1967 di Bangkok, Thailand oleh lima negara pendiri, yaitu Indonesia, Malaysia, Filipina, Singapura, dan Thailand melalui penandatanganan "Deklarasi Bangkok".

Pembentukan ASEAN dilatarbelakangi keinginan kuat dari para pendiri ASEAN untuk menciptakan kawasan Asia Tenggara yang damai, aman, stabil dan sejahtera. Hal tersebut mengemuka karena situasi di kawasan pada era 1960-an dihadapkan pada situasi rawan konflik, yaitu perebutan pengaruh ideologi antar kekuatan militer negara-negara besar dan konflik antar negara di kawasan yang apabila dibiarkan dapat mengganggu stabilitas kawasan sehingga mempersulit pelaksanaan pembangunan.

Lima orang wakil Negara/Pemerintahan negara-negara di Asia Tenggara yang menandatangani Deklarasi Bangkok pada tahun 1967, yaitu:

1. Menteri Luar Negeri Filipina (Narciso R. Ramos)

2. Menteri Luar Negeri Indonesia (Adam Malik)

3. Menteri Luar Negeri Thailand (Thanat Khoman)

4. Menteri Pertahanan dan Menteri Pembangunan Nasional Malaysia (Tun Abdul Razak)

5. Menteri Luar Negeri Singapura (S. Rajaratnam)

Pada perkembangannya, lima negara dikawasan Asia Tenggara selanjutnya menyusul bergabung dalam ASEAN, yakni Brunei Darussalam (8 Januari 1984); Vietnam (28 Juli 1995); Laos dan Myanmar (23 Juli 1997); serta Kamboja (30 April 1999)[3].

\section{Visual Basic}

Visual Basic merupakan bahasa pemrograman yang sangat mudah dipelajari, dengan teknik pemrograman visual yang memungkinkan penggunanya untuk berkreasi lebih baik dalam menghasilkan suatu program aplikasi. Ini terlihat dari dasar pembuatan dalam visual basic adalah FORM, dimana pengguna dapat mengatur tampilan form kemudian dijalankan dalam script yang sangat mudah.

Ledakan pemakaian Visual Basic ditandai dengan kemampuan Visual Basic untuk dapat berinteraksi dengan aplikasi lain di dalam sistem operasi Windows dengan komponen ActiveX Control. Dengan komponen ini memungkinkan pengguna untuk memanggil dan menggunakan semua model data yang ada di dalam sistem operasi Windows. Hal ini juga ditunjang dengan teknik pemrograman di dalam Visual Basic yang mengadopsi dua macam jenis pemrograman yaitu Pemrograman Visual dan Object Oriented Programming (OOP)[4].

\section{METODE PENELITIAN}

Pada penelitian kali ini, penulis menggunakan teknik pengumpulan data yang meliputi:

1. Observasi

Melakukan pengamatan langsung aplikasi-aplikasi yang digunakan sebagai media pembelajaran.

2. Wawancara

Melakukan tanya jawab langsung kepada para calon pengguna aplikasi ini mengenai apa saja fitur-fitur yang mereka inginkan untuk dikembangkan dalam aplikasi Atlas Asean ini.

3. Studi Pustaka

Mempelajari hal-hal yang berkaitan dengan penelitian kali ini. Seperti atlas, ASEAN, Visual Basic dari berbagai macam referensi baik berupa buku, software, dan sumbersumber lain dari internet.

Semua tahapan diatas dilakukan demi tercapainya suatu pengembangan aplikasi pembelajaran yang tepat guna, dan sesuai dengan selera penggunanya.

\section{PEMBAHASAN DAN HASIL}

\section{A. Analisa Kebutuhan Aplikasi}

Berdasarkan penelitian yang dilakukan, maka kebutuhan fitur-fitur yang harus disediakan pada aplikasi Atlas ASEAN adalah:

1. Aplikasi menyediakan gambar peta dari semua anggota ASEAN. Lengkap dengan legenda peta, dan profil negaranegara anggotanya

2. Aplikasi menyediakan fitur zoom in/zoom out (perbesar/perkecil) gambar peta, agar lebih mudah dilihat, dibaca dan disesuaikan dengan tingkat kenyamanan penggunanya.

3. Aplikasi menyediakan profil sejarah tentang ASEAN.

4. Aplikasi menjalankan audio atau suara yang akan muncul sesuai dengan permintaan pengguna.

5. Aplikasi bisa melakukan perintah print out atau pencetakan pada gambar peta.

6. Aplikasi memiliki fitur pencari untuk menemukan kotakota pada tiap negara.

7. Aplikasi bisa dijalankan tanpa membutuhkan resource komputer yang besar dan berat.

\section{B. Storyboard}

Berikut adalah pemaparan rancangan tampilan aplikasi Atlas ASEAN secara umum. 


\section{Storyboard Menu Utama}

Menu Utama terdiri
dari 6 tombol, 1
label, dan 2 gambar.
Serta ada 10 option
button yang mewa-
kili jumlah negara
anggota ASEAN.
Adapun fungsi tom-
bol tertera pada
gambar.

Sumber Hasil Penelitian (2021)

\section{Gbr. 1 Storyboard Menu Utama}

\section{Storyboard Peta}

\begin{tabular}{|l|l|c|}
\hline \multicolumn{1}{|c|}{ Visual } & Audio \\
\hline Pada form ini \\
tersedia tombol ce- \\
tak, legenda, profil \\
negara dan juga fitur \\
zoom in-zoom out \\
peta, search engine \\
pencarian kota, dan \\
sebagainya. \\
Thumbnail Navigasi \\
aktif saat peta dalam \\
posisi zoom in, digu- \\
nakan untuk meng- \\
geser gambar peta.
\end{tabular}

Sumber Hasil Penelitian (2021)

Gbr. 2 Storyboard Peta

\section{Storyboard About}

\begin{tabular}{|l|l|l|l|}
\hline \multicolumn{1}{|c|}{ Visual } & \multicolumn{1}{|c|}{ Sudio } \\
\hline $\begin{array}{l}\text { Pada form ini } \\
\text { tersedia gambar lo- } \\
\text { go ASEAN dan teks } \\
\text { berjalan yang berisi } \\
\text { informasi tentang } \\
\text { detail program. }\end{array}$ \\
$\begin{array}{l}\text { Tombol Exit untuk } \\
\text { menutup form ini. }\end{array}$
\end{tabular}

Sumber Hasil Penelitian (2021)

Gbr. 3 Storyboard About

\section{Storyboard Profil}

\begin{tabular}{|l|l|l|l|}
\hline Visual & Sketsa & Audio \\
\hline Pada form ini \\
terdapat gambar lo- \\
go ASEAN dan \\
profil mengenai se- \\
jarah singkat \\
ASEAN. \\
Isi profil akan \\
berubah sesuai ne- \\
gara yang dipilih. \\
Tombol Exit untuk \\
menutup form ini
\end{tabular}

Sumber Hasil Penelitian (2021)

Gbr. 4 Storyboard Profil

\section{Storyboard Legenda}

\begin{tabular}{|l|l|l|l|}
\hline \multicolumn{2}{|c|}{ Visual } & \multicolumn{1}{c|}{ Sketsa } & \\
\hline Pada form ini \\
terdapat gambar lo- \\
go ASEAN dan \\
legenda peta. \\
Klik Peta untuk \\
menampilkan legen- \\
da peta secara \\
umum. \\
Klik Negara untuk \\
menampilkan legen- \\
da peta tiap negara. \\
Tombol Exit untuk \\
menutup form ini
\end{tabular}

Sumber Hasil Penelitian (2021)

Gbr. 5 Storyboard Legenda

6. Storyboard Photo

\begin{tabular}{|l|l|l|}
\hline \multicolumn{1}{|c|}{ Visual } & \multicolumn{1}{|c|}{ Sketsa } & Audio \\
\hline Pada form ini \\
terdapat gambar pa- \\
norama tiap-tiap ne- \\
gara anggota. Juga \\
keterangan singkat \\
tentang panorama \\
tersebut. \\
Panorama akan be- \\
rubah sesuai dengan \\
negara yang dipilih. \\
Klik kanan pada \\
foto panorama untuk \\
mencetak foto ter- \\
sebut.
\end{tabular}

Gbr. 6 Storyboard Photo

\section{User Interface}

Pada poin ini akan ditampilkan output dengan user interface yang disesuaikan dengan rancangan storyboard pada poin sebelumnya.

\section{Form Menu Utama}

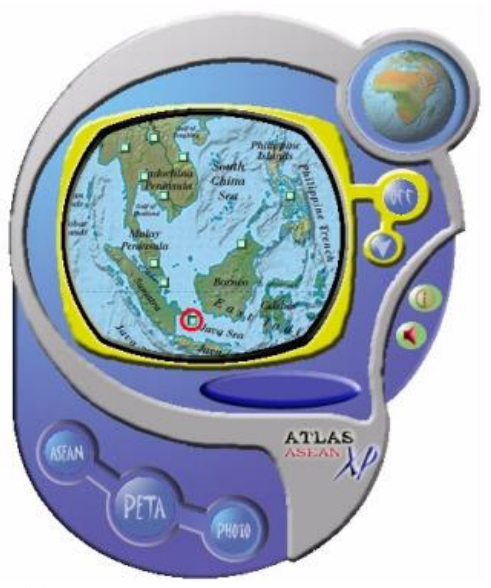

Sumber Hasil Penelitian (2021)

Gbr. 7 Form Menu Utama 


\section{Form Peta}

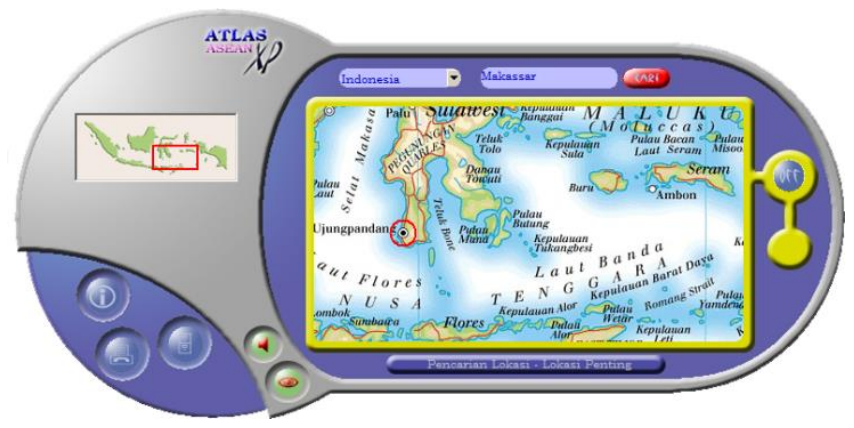

Sumber Hasil Penelitian (2021)

Gbr.8 Form Peta

\section{Form About}

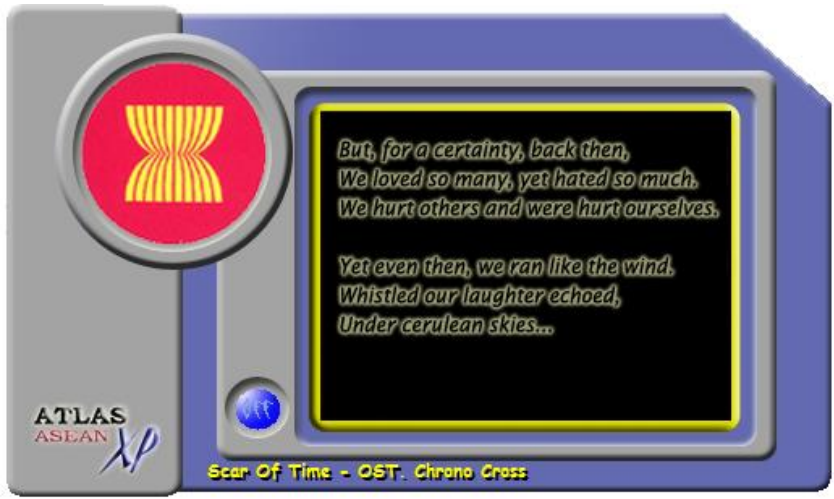

Sumber Hasil Penelitian (2021)

Gbr.9 Form About

\section{Form Profil}

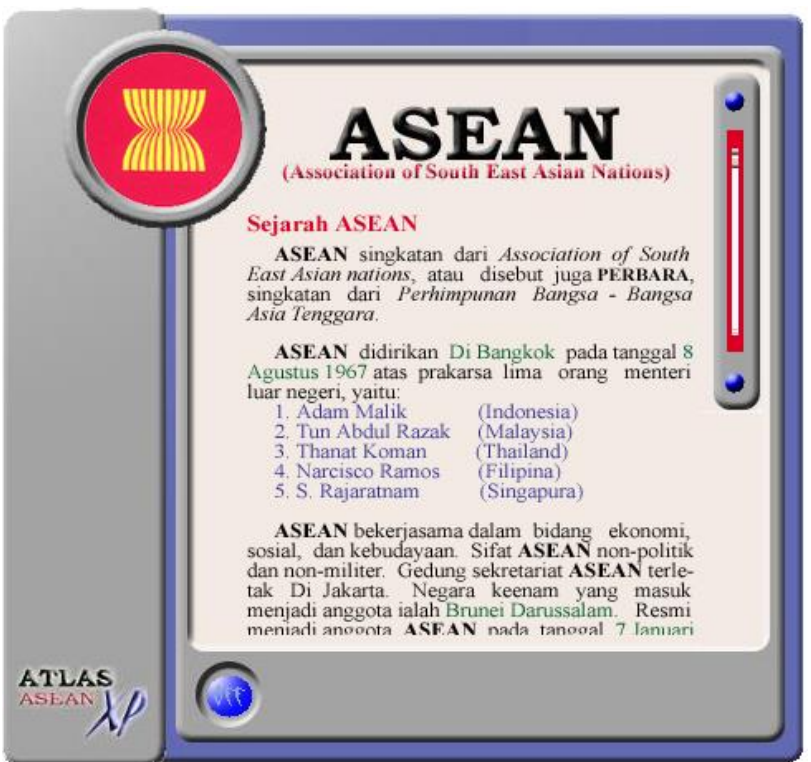

Sumber Hasil Penelitian (2021)

Gbr.10 Form Profil

\section{Form Legenda}

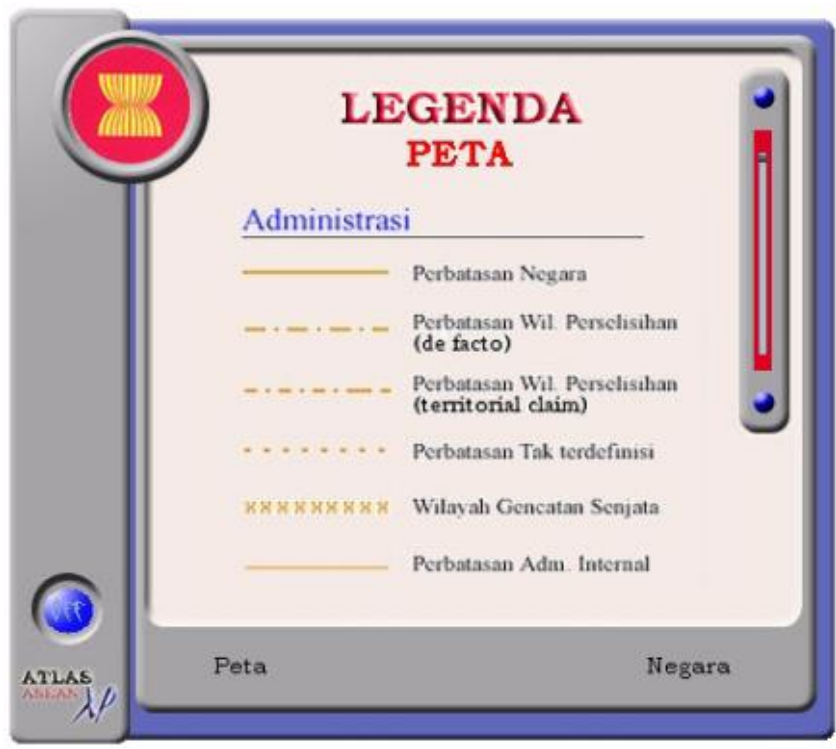

Sumber Hasil Penelitian (2021)

Gbr.11 Form Legenda

\section{Form Photo}

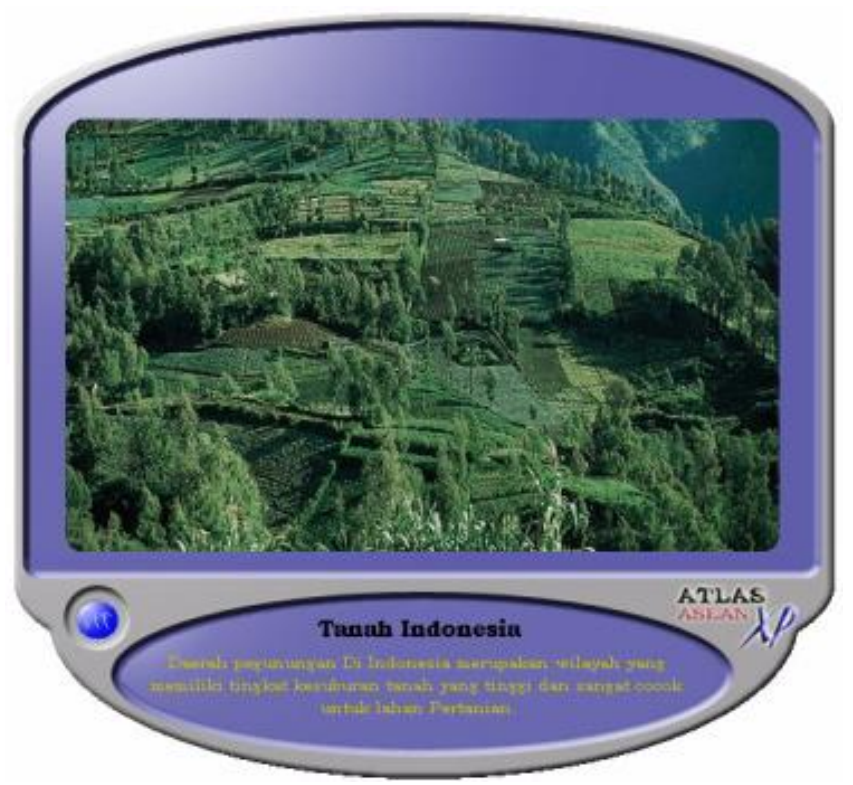

Sumber Hasil Penelitian (2021)

Gbr.11 Form Photo

\section{Pengujian}

Aplikasi yang telah rampung dibuat, selanjutnya akan diuji menggunakan teknik pengujian Black Box Testing yang meliputi pengujian sistem atau komponen dengan mempertimbangkan input, output, dan fungsi sesuai dengan spesifikasi[5]. Pengujian ini ditujukan untuk memastikan bahwa suatu event yang terjadi pada aplikasi Atlas ASEAN ini 
menghasilkan output sesuai dengan yang diharapkan. Adapun poin-poin yang diujikan adalah sebagai berikut :

TABEL 1

PENGUJIAN FORM MENU UTAMA

\begin{tabular}{|c|c|c|c|}
\hline $\begin{array}{l}\text { Input } \\
\text { Event }\end{array}$ & Proses & $\begin{array}{c}\text { Output } \\
\text { NextStage }\end{array}$ & $\begin{array}{c}\text { Hasil } \\
\text { Uji }\end{array}$ \\
\hline $\begin{array}{l}\text { Klik tombol } \\
\text { Peta }\end{array}$ & $\begin{array}{l}\text { Command } 1(0) . \text { Enabled }= \\
\text { False } \\
\text { Form2.Show }\end{array}$ & $\begin{array}{l}\text { Tampil } \\
\text { Form Peta }\end{array}$ & Sesuai \\
\hline $\begin{array}{l}\text { Klik tombol } \\
\text { Profil }\end{array}$ & $\begin{array}{l}\text { Command1(1). Enabled = } \\
\text { False } \\
\text { Form4.Show }\end{array}$ & $\begin{array}{l}\text { Tampil } \\
\text { Form Profil } \\
\text { ASEAN }\end{array}$ & Sesuai \\
\hline $\begin{array}{l}\text { Klik tombol } \\
\text { Photo }\end{array}$ & $\begin{array}{l}\text { Command1(2). Enabled = } \\
\text { False } \\
\text { Form5.Show }\end{array}$ & $\begin{array}{l}\text { Tampil } \\
\text { Form Photo } \\
\text { yang } \\
\text { menampilkan } \\
\text { panorama } \\
\text { negara yang } \\
\text { dipilih } \\
\end{array}$ & Sesuai \\
\hline $\begin{array}{l}\text { Klik tombol } \\
\text { Exit }\end{array}$ & $\begin{array}{l}\text { Call wavPlay("clear.wav") } \\
\text { End }\end{array}$ & $\begin{array}{l}\text { Keluar dari } \\
\text { aplikasi Atlas } \\
\text { ASEAN }\end{array}$ & Sesuai \\
\hline $\begin{array}{l}\text { Klik tombol } \\
\text { About }\end{array}$ & $\begin{array}{l}\text { Command1(5). Enabled = } \\
\text { False } \\
\text { Form3.Show }\end{array}$ & $\begin{array}{l}\text { Tampil } \\
\text { Form About }\end{array}$ & Sesuai \\
\hline $\begin{array}{l}\text { Klik tombol } \\
\text { Sebut }\end{array}$ & $\begin{array}{l}\text { Select Case Label2.Caption } \\
\text { Case "Indonesia": } \\
\text { Call wavPlay("Indo.wav") } \\
\text { Case "Malaysia": } \\
\text { Call wavPlay("Mlay.wav") } \\
\text { Case "Brunei": } \\
\text { Call wavPlay("Brun.wav") } \\
\text { Case "Burma (Myanmar)": } \\
\text { Call wavPlay("Brm.wav") } \\
\text { Case "Filipina": } \\
\text { Call wavPlay("Filip.Wav") } \\
\text { Case "Kamboja": } \\
\text { Call wavPlay("Kbja.wav") } \\
\text { Case "Laos": } \\
\text { Call wavPlay("laos.Wav") } \\
\text { Case "Singapura": } \\
\text { Call wavPlay("Sing.wav") } \\
\text { Case "Thailand": } \\
\text { Call wavPlay("Thai.Wav") } \\
\text { Case "Vietnam": } \\
\text { Call wavPlay("viet.wav") } \\
\text { End Select }\end{array}$ & $\begin{array}{l}\text { Jalankan file } \\
\text { audio yang } \\
\text { menyebutkan } \\
\text { nama negara } \\
\text { yang dipilih }\end{array}$ & Sesuai \\
\hline
\end{tabular}

TABEL 2

PENGUJIAN FORM PETA

\begin{tabular}{|c|c|c|c|}
\hline $\begin{array}{l}\text { Input } \\
\text { Event }\end{array}$ & Proses & $\begin{array}{c}\text { Output } \\
\text { NextStage }\end{array}$ & $\begin{array}{c}\text { Hasil } \\
\text { Uji }\end{array}$ \\
\hline $\begin{array}{l}\text { Klik tombol } \\
\text { Profil }\end{array}$ & $\begin{array}{l}\text { Command1(0). Enabled = } \\
\text { False } \\
\text { Combo1.Enabled = False } \\
\text { Form7.Show }\end{array}$ & $\begin{array}{l}\text { Tampil } \\
\text { Form Profil } \\
\text { Negara }\end{array}$ & Sesuai \\
\hline $\begin{array}{l}\text { Klik tombol } \\
\text { Cetak }\end{array}$ & $\begin{array}{l}\text { Printer.PaintPicture } \\
\text { Picture4, Printer.CurrentX, } \\
\text { Printer.CurrentY } \\
\text { Printer.EndDoc }\end{array}$ & $\begin{array}{l}\text { Cetak peta } \\
\text { pada kertas }\end{array}$ & Sesuai \\
\hline $\begin{array}{l}\text { Klik tombol } \\
\text { Legenda }\end{array}$ & $\begin{array}{l}\text { Command1(2).Enabled= } \\
\text { False } \\
\text { Combo1. Enabled = False } \\
\text { Picture4.Enabled = False } \\
\text { Form6.Show }\end{array}$ & $\begin{array}{l}\text { Tampil } \\
\text { Form } \\
\text { Legenda }\end{array}$ & Sesuai \\
\hline $\begin{array}{l}\text { Klik tombol } \\
\text { Sebut }\end{array}$ & $\begin{array}{l}\text { Select Case Combo1.Text } \\
\text { Case "Indonesia": } \\
\text { Call wavPlay("Indo.wav") } \\
\text { Case "Malaysia": } \\
\text { Call wavPlay("Mlay.wav") } \\
\text { Case "Brunei": } \\
\text { Call wavPlay("Brun.wav") } \\
\text { Case "Burma (Myanmar)": } \\
\text { Call wavPlay("Brm.wav") } \\
\text { Case "Filipina": } \\
\text { Call wavPlay("Filip.Wav") } \\
\text { Case "Kamboja": } \\
\text { Call wavPlay("Kbja.wav") } \\
\text { Case "Laos": } \\
\text { Call wavPlay("laos.Wav") } \\
\text { Case "Singapura": } \\
\text { Call wavPlay("Sing.wav") } \\
\text { Case "Thailand": } \\
\text { Call wavPlay("Thai.Wav") } \\
\text { Case "Vietnam": } \\
\text { Call wavPlay("viet.wav") } \\
\text { End Select }\end{array}$ & $\begin{array}{l}\text { Jalankan file } \\
\text { audio yang } \\
\text { menyebutkan } \\
\text { nama negara } \\
\text { yang dipilih }\end{array}$ & Sesuai \\
\hline $\begin{array}{l}\text { Klik tombol } \\
\text { Photo }\end{array}$ & $\begin{array}{l}\text { Command1(4). Enabled = } \\
\text { False } \\
\text { Form5.Show }\end{array}$ & $\begin{array}{l}\text { Tampil Form } \\
\text { Photo yang } \\
\text { menampilkan } \\
\text { panorama } \\
\text { negara yang } \\
\text { dipilih } \\
\end{array}$ & Sesuai \\
\hline $\begin{array}{l}\text { Klik tombol } \\
\text { Exit }\end{array}$ & $\begin{array}{l}\text { Form1.Command1(0).Enab } \\
\text { led = True } \\
\text { Unload Form7 } \\
\text { Unload Form8 } \\
\text { Unload Form6 } \\
\text { Unload Form2 }\end{array}$ & $\begin{array}{l}\text { Tutup Form } \\
\text { Peta dan } \\
\text { kembali ke } \\
\text { Form Menu } \\
\text { Utama }\end{array}$ & Sesuai \\
\hline $\begin{array}{l}\text { Klik tombol } \\
\text { Cari }\end{array}$ & $\begin{array}{l}\text { Picture5.Visible = False } \\
\text { CurXY } \\
\text { Call wavPlay("beep.wav") }\end{array}$ & $\begin{array}{l}\text { Atur posisi } \\
\text { peta fokus } \\
\text { menampilkan } \\
\text { letak kota } \\
\text { yang diketik } \\
\text { pada textbox } \\
\text { dan tampil } \\
\text { animasi radar } \\
\text { pada kota } \\
\text { yang dituju }\end{array}$ & Sesuai \\
\hline
\end{tabular}


VOL. VII NO. 2 AGUSTUS 2021

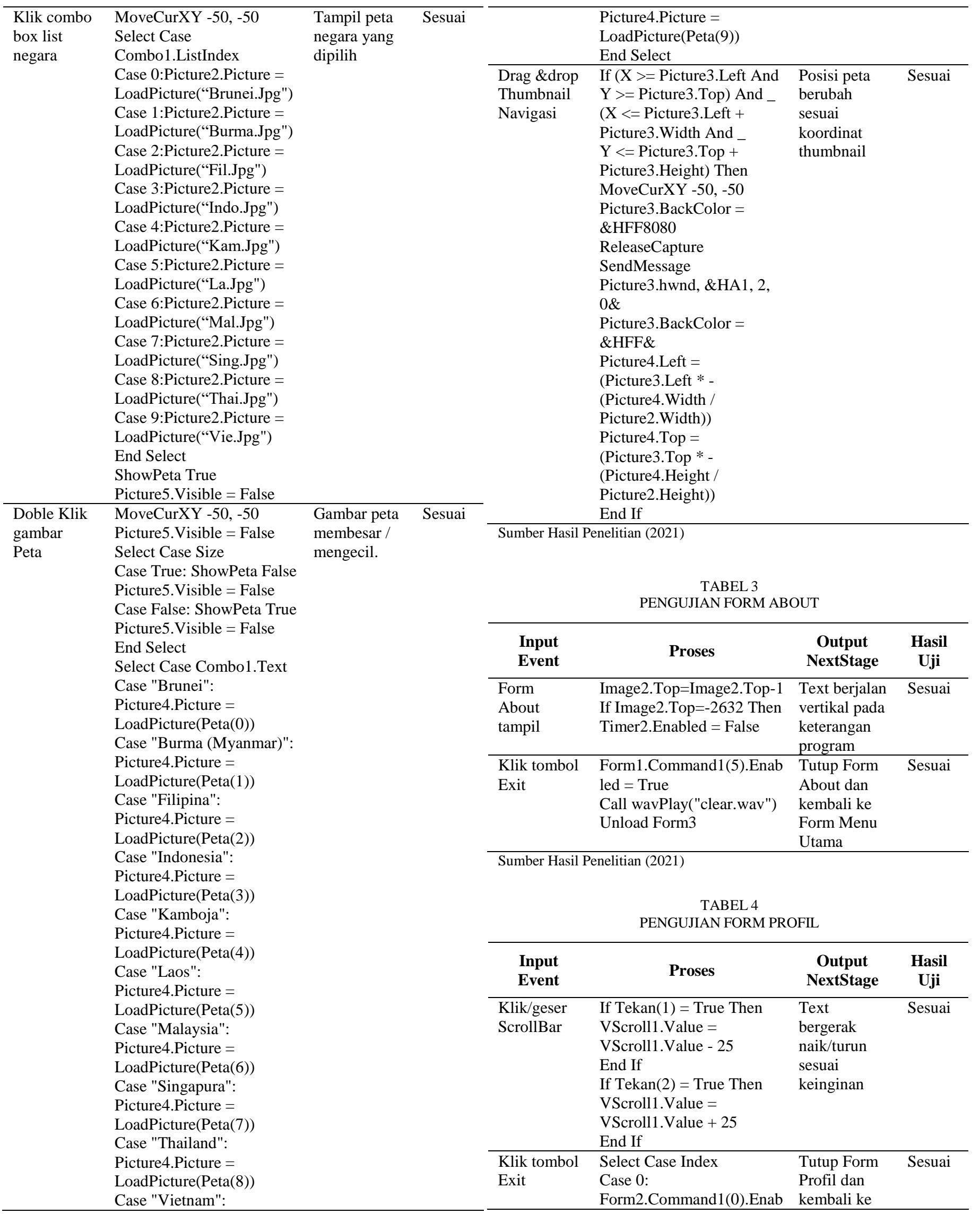




\begin{tabular}{ll}
\hline led $=$ True: & form \\
Form2.Combo1.Enabled $=$ & sebelumnya \\
True & \\
Unload Form7 & \\
End Select & \\
\hline
\end{tabular}

Sumber Hasil Penelitian (2021)

TABEL 5

PENGUJIAN FORM LEGENDA

\begin{tabular}{|c|c|c|c|}
\hline $\begin{array}{l}\text { Input } \\
\text { Event }\end{array}$ & Proses & $\begin{array}{c}\text { Output } \\
\text { NextStage }\end{array}$ & $\begin{array}{c}\text { Hasil } \\
\text { Uji }\end{array}$ \\
\hline $\begin{array}{l}\text { Klik/geser } \\
\text { ScrollBar }\end{array}$ & $\begin{array}{l}\text { If Tekan }(1)=\text { True Then } \\
\text { VScroll1.Value }= \\
\text { VScroll1.Value }-25 \\
\text { End If } \\
\text { If Tekan }(2)=\text { True Then } \\
\text { VScroll1.Value = } \\
\text { VScroll1.Value }+25 \\
\text { End If }\end{array}$ & $\begin{array}{l}\text { Text } \\
\text { bergerak } \\
\text { naik/turun } \\
\text { sesuai } \\
\text { keinginan }\end{array}$ & Sesuai \\
\hline $\begin{array}{l}\text { Klik Label } \\
\text { Peta }\end{array}$ & $\begin{array}{l}\text { Label1(2).Caption }= \\
\text { UCase(Label1(0).Caption) } \\
\text { VScroll1.Value }=0 \\
\text { VScroll1.Max }=1300 \\
\text { Image1.Picture = } \\
\text { LoadPicture("legenda.jpg") }\end{array}$ & $\begin{array}{l}\text { Tampil } \\
\text { legenda peta } \\
\text { secara umum }\end{array}$ & Sesuai \\
\hline $\begin{array}{l}\text { Klik Label } \\
\text { Negara }\end{array}$ & $\begin{array}{l}\text { Label1(2).Caption = } \\
\text { UCase(Label1(1).Caption) } \\
\text { VScroll1.Value = } 0 \\
\text { VScroll1.Max = 50 } \\
\text { Select Case } \\
\text { Form2.Combo1.Text } \\
\text { Case "Brunei": } \\
\text { Image1.Picture = } \\
\text { LoadPicture("Brunei.Jpg") } \\
\text { Case "Burma (Myanmar)": } \\
\text { Image1.Picture = } \\
\text { LoadPicture("Burma.Jpg") } \\
\text { Case "Filipina": } \\
\text { Image1.Picture = } \\
\text { LoadPicture("Fil.Jpg") } \\
\text { Case "Indonesia": } \\
\text { Image1.Picture = } \\
\text { LoadPicture("Indo.Jpg") } \\
\text { Case "Kamboja": } \\
\text { Image1.Picture = } \\
\text { LoadPicture("Kam.Jpg") } \\
\text { Case "Laos": } \\
\text { Image1.Picture = } \\
\text { LoadPicture("La.Jpg") } \\
\text { Case "Malaysia": } \\
\text { Image1.Picture = } \\
\text { LoadPicture("Mal.Jpg") } \\
\text { Case "Singapura": } \\
\text { Image1.Picture = } \\
\text { LoadPicture("Sing.Jpg") } \\
\text { Case "Thailand": } \\
\text { Image1.Picture = } \\
\text { LoadPicture("Thai.Jpg") } \\
\text { Case "Vietnam": } \\
\text { Image1.Picture = } \\
\text { LoadPicture("Vie.Jpg") } \\
\end{array}$ & $\begin{array}{l}\text { Tampil } \\
\text { legenda peta } \\
\text { per negara }\end{array}$ & Sesuai \\
\hline
\end{tabular}

\begin{tabular}{|c|c|c|c|}
\hline & $\begin{array}{l}\text { End Select } \\
\text { End Select }\end{array}$ & & \\
\hline $\begin{array}{l}\text { Klik Tombol } \\
\text { Exit }\end{array}$ & $\begin{array}{l}\text { Select Case Index } \\
\text { Case 0: } \\
\text { Form2.Command1(2).Enab } \\
\text { led = True: } \\
\text { Form2.Combo1.Enabled = } \\
\text { True } \\
\text { Form2.Picture4.Enabled = } \\
\text { True: Unload Form6 } \\
\text { End Select }\end{array}$ & $\begin{array}{l}\text { Tutup Form } \\
\text { Legenda dan } \\
\text { kembali ke } \\
\text { Form Peta }\end{array}$ & Sesuai \\
\hline Sumber Hasil P & $\begin{array}{c}\text { TABEL } 6 \\
\text { PENGUJIAN FORM PH }\end{array}$ & ОTO & \\
\hline $\begin{array}{l}\text { Input } \\
\text { Event }\end{array}$ & Proses & $\begin{array}{c}\text { Output } \\
\text { NextStage }\end{array}$ & $\begin{array}{c}\text { Hasil } \\
\text { Uji }\end{array}$ \\
\hline $\begin{array}{l}\text { Klik kanan } \\
\text { pada Gambar } \\
\text { Panorama }\end{array}$ & $\begin{array}{l}\text { If Button }=2 \text { Then } \\
\text { Printer.PaintPicture } \\
\text { Picture2, Printer.CurrentX, } \\
\text { Printer.CurrentY } \\
\text { Printer.EndDoc } \\
\text { End If }\end{array}$ & $\begin{array}{l}\text { Cetak } \\
\text { gambar } \\
\text { panorama } \\
\text { pada kertas }\end{array}$ & Sesuai \\
\hline $\begin{array}{l}\text { Klik Tombol } \\
\text { Exit }\end{array}$ & $\begin{array}{l}\text { Form2.Command1(4).Enab } \\
\text { led = True } \\
\text { Form2.Combo1.Enabled = } \\
\text { True } \\
\text { Unload Form8 }\end{array}$ & $\begin{array}{l}\text { Tutup Form } \\
\text { Photo dan } \\
\text { kembali ke } \\
\text { form } \\
\text { sebelumnya }\end{array}$ & Sesuai \\
\hline
\end{tabular}

Sumber Hasil Penelitian (2021)

\section{E. Kebutuhan Hardware Dan Software}

Adapun pengujian aplikasi ini menggunakan sistem komputer dengan spesifikasi sebagai berikut:

1. Sistem Operasi Microsoft Windows ME

2. Prosesor Intel Pentium 2

3. RAM $128 \mathrm{MB}$

4. VGA $8 \mathrm{MB}$

5. Monitor Resolusi 1024 x 768

6. Soundcard

7. Ruang harddisk sebesar $\pm 85 \mathrm{MB}$

8. Keyboard dan mouse

Penulis sengaja melakukan test running dengan spesifikasi rendah seperti diatas, untuk mengetahui seberapa ringan aplikasi ini membutuhkan resource sistem komputer. Dan ternyata meskipun dengan spesifikasi minimalis seperti diatas, Aplikasi Atlas ASEAN ini bisa berjalan tanpa ada kendala sama sekali. 


\section{KESIMPULAN}

Berdasarkan pemaparan yang telah penulis sampaikan dan dari hasil pengujian aplikasi Atlas ASEAN, maka disimpulkan beberapa hal sebagai berikut :

1. Aplikasi Atlas ASEAN ini diharapkan dapat membantu dan memudahkan kegiatan belajar maupun mengajar, dalam hal ini mengenai organisasi ASEAN

2. Aplikasi Atlas ASEAN ini memberikan fitur-fitur yang sangat mudah penggunaannya, disertai dengan user interface yang unik dan variatif sehingga aplikasi ini berbeda dari aplikasi sejenis lainnya, sehingga memungkinkan penggunanya untuk lebih bisa menikmati penggunaan aplikasi ini.

3. Aplikasi Atlas ASEAN ini memiliki beberapa keunggulan dibanding dengan aplikasi sejenis. Yaitu aplikasi ini merupakan gabungan dari aplikasi peta dan aplikasi ensiklopedia. selain itu aplikasi ini dapat dijalankan dengan spesifikasi komputer yang terbilang minimum.

4. Penggunaan Microsoft Visual Basic dalam pembuatan aplikasi Atlas ASEAN ini dinilai sangat menguntungkan karena seperti yang kita ketahui aplikasi yang dibuat dengan Visual Basic mampu dijalankan pada banyak versi sistem operasi Windows tanpa perlu menginstall aplikasi tambahan yang justru dapat memberatkan proses pada Windows.

5. Penulis berharap kelak aplikasi Atlas ASEAN ini juga dikembangkan untuk bisa dijalankan pada banyak platform, seperti pada Android, iOS atau sistem operasi lainnya.

6. Harapan kedepannya semoga aplikasi sejenis bisa terus berkembang baik dari segi kuantitas dan kuantitas demi membantu kegiatan belajar mengajar agar lebih mudah dan menyenangkan.

\section{UCAPAN TERIMA KASIH}

Ucapan syukur yang sebesar-besarnya kepada Allah Subhanahu Wa Ta'ala atas segala keberkahan yang telah diberikan hingga saat ini. Juga ucapan terima kasih yang sebesar-besarnya kepada Tim JTI STMIK Antar Bangsa yang telah memberikan waktu dan kemudahan bagi penulis untuk bisa mempublikasikan penelitian ilmiah ini. Semoga kelak kita semua bisa kembali bekerjasama di jalan kebaikan dalam hal apapun. Aamiiiiin.

\section{REFERENSI}

[1] M. Yaumi, "MEDIA PEMBELAJARAN: Pengertian, Fungsi, dan Urgensinya bagi Anak Milenial," Seminar Nasinal tentang Pemanfaat. Media bagi Anak Milenial., vol. 4, pp. 9-15, 2017.

[2] A. Ridho, "MEDIA PETA DAN ATLAS (PA) DALAM PEMBELAJARAN IPS (Studi Eksperimen intact-Group Comparison Design terhadap Hasil Belajar IPS Siswa Kelas IV SDN 06 Cakranegara Tahun 2016)," Program Studi Pendidik. Guru Sekolah Dasar Fakultas. Keguruan dan Ilmu Pendidik. Universitas Mataram, 2016.

[3] K. L. N. Ditjen Kerja Sama ASEAN, "ASEAN Selayang Pandang," Ditjen Kerja Sama ASEAN, Kementerian Luar Negeri, vol. 22, pp. 1$101,2017$.
[4] A. Basuki, "Algoritma Pemrogaman Menggunakan Visual Basic 6.0," Institut Teknologi Sepuluh Nopember Surabaya, p. 157, 2006.

[5] M. A Rohman and D. Kasoni, "Prototype Game Pencegahan Demam Berdarah Dengue Menggunakan Unity 2D," Jurnal Teknik Informatika STMIK Antar Bangsa, vol. VI, no. 2, pp. 58-62, 2020, [Online]. Available:

https://ejournal.antarbangsa.ac.id/index.php/jti/article/view/333.

[6] A. C. Febriawan, J. Siregar, and C. Cahyadi, "Program Animasi Interaktif Pengenalan Kebudayaan Indonesia," Jurnal Teknik Informatika STMIK Antar Bangsa, vol. IV, no. 2, pp. 119-124, 2018.

[7] L. Mazia and E. Pujiastuti, "Rancang Bangun Media Pembelajaran dan Game Kebudayaan Dari 34 Propinsi di Indonesia Berbasis Android," Jurnal Teknik Informatika STMIK Antar Bangsa,, vol. IV, no. 2, pp. 195-203, 2018.

[8] D. Sutisna, "Media Interaktif Pengenalan Profesi Untuk Anak Usia Dini Berbasis Android," Jurnal Teknik Informatika STMIK Antar Bangsa, vol. IV, no. 1, pp. 99-104, 2018, [Online]. Available: http://repositori.unsil.ac.id/132/.

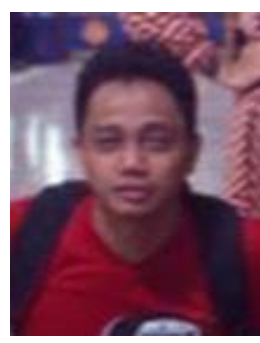

Herryansyah. Lahir di Jakarta pada tanggal 4 September 1982. Pada tahun 2005 lulus dari Program Strata Satu (S1), Program Studi Sistem Informasi Universitas Gunadarma. Tahun 2015 lulus dari Magister Ilmu Komputer Program Pascasarjana STMIK Nusa Mandiri. Saat ini aktif sebagai tenaga pengajar di Universitas Bina Sarana Informatika 